UDC 661.183:661.155.5:667.2

\title{
APPLICATION OF AGRICULTURE WASTE AS BIOSORBENTS FOR DYE REMOVAL FROM AQUEOUS SOLUTIONS
}

\author{
L.M. Soldatkina *, M.A. Zavrichko \\ Mechnikov National University of Odessa \\ 2 Dvoryanskaya Str., Odessa, 65082, Ukraine
}

The efficiency of unmodified and modified biosorbents (barley straw and Jerusalem artichoke stalks) in removing anionic (Acid Red) and cationic (Methylene Blue) dyes from their aqueous solutions has been studied. That the adsorption of dye onto unmodified and modified barley straw and Jerusalem artichoke stalks was found to be strongly affected by the $\mathrm{pH}$ value. The optimum $\mathrm{pH}$ is in the range of 6-10 for cationic dye and 2-3 for anionic one. The kinetic curves of cationic and anionic dye adsorption on barley straw and Jerusalem artichoke stalks are well described with the help of pseudo-second order kinetic equation. Studied biosorbents are natural, eco-friendly, and low-cost adsorbents and they can be an alternative to expensive activated carbons.

\section{INTRODUCTION}

Synthetic dyes are widely used in the textile, paper, leather, fur and the printing industry for coloring their products. Dye wastewater must not get into the environment because many dyes have toxic (such as mutagenic, allergenic, and carcinogenic) effects on aquatic life and humans. Many methods have been employed to remove the dyes from wastewater [1]. These methods include precipitation, oxidation, coagulation, flotation, and adsorption. However, in all those methods the adsorption has a special place in dye removal because it is the most effective method for removal various dyes.

The full introduction of adsorption technology in to the practice of deep cleaning of dye wastewater is inhibited by high cost of activated carbons and by problems with their regeneration [2]. In recent years, attention of chemists has been focused on low-cost adsorbents (biosorbents) from agricultural waste. The agricultural countries have abundant source of straw, stalks, hulls, leaves etc. In Ukraine barley is the second cereal crop after wheat. Threshing of 1 ton of barley grain produces 1 ton of barley straw [3]. Jerusalem artichoke is used as industrial, forage, food, health crops and as a biomeliorant. 150 ton stalks per ha are formed after harvest Jerusalem artichoke tubers [4].

\footnotetext{
* corresponding author soldatkina@onu.edu.ua
} ХФТП 2013. Т. 4. № 1
Agricultural waste is partly used as roughage and bedding for cattle, a source of energy for home heating and power generation, a soil amendment that facilitates the formation of humus. Unclaimed agricultural waste is burned on the fields. This is the cause of origin of a number of environmental regional and even global problems: the humus layer burns down in the soil of $10 \mathrm{~cm}$, microorganisms that transform plant residues are destroyed, the biological activity of the soil is reduced, emissions of carbon gas are increased, a risk of fires is appeared.

Barley straw and Jerusalem artichoke stalks are characterized by a unique chemical composition and can be successfully used as a cheap raw material for new adsorbents and as an alternative of activated carbons. These materials contain natural polymers. The composition of barley straw is as follows (wt. \%) [5]: cellulose - 34; lignin - 14; hemicellulose -22 , that of Jerusalem artichoke stalks being cellulose - 28; lignin - 17; hemicellulose - 7(wt. \%) [6].

In this paper, barley straw and Jerusalem artichoke stalks were studied to determine their efficiency in removing dyes from their aqueous solutions. In order to increase the adsorption capacities of agricultural waste, these materials were modified by cetylpyridinium bromide (as biosorbents for anionic dye adsorption) and by citric acid (as those for cationic dye adsorption). 


\section{EXPERIMENTAL}

Barley straw and Jerusalem artichoke stalks were obtained from Izmail district of Odessa region. These materials were dried at room temperature, milled into electrical universal grinder and sieved to retain the fraction $<250 \mu \mathrm{m}$. This fraction was used for preparing unmodified and modified biosorbents.

Ground barley straw and Jerusalem artichoke stalks were boiled in distilled water (at the ratio $1: 20, \mathrm{w} / \mathrm{v})$ for $1 \mathrm{~h}$, washed to $\mathrm{pH}=6.0$ with distilled water and dried at $323 \mathrm{~K}$ until the constant weight. After this treatment the samples of biosorbents were designated: unmodified barley straw - BS, Jerusalem artichoke stalks - JAS.

BS and JAS were immersed in $0.5 \mathrm{~mol} / \mathrm{L}$ citric acid (at the ratio $1: 12, \mathrm{w} / \mathrm{v}$ ) and stirred at $293 \mathrm{~K}$ for $24 \mathrm{~h}$. Then reaction between citric acid and unmodified biosorbents was performed at $393 \mathrm{~K}$ for $90 \mathrm{~min}$. After cooled down to the room temperature, the citric acid-esterifying biosorbents were washed to $\mathrm{pH}=6$ with distilled water and dried at $323 \mathrm{~K}$ until the constant weight. After modification by citric acid the samples of biosorbents were designated: modified barley straw - BS-C, Jerusalem artichoke stalks - JAS-C.

BS and JAS were immersed in $2.5 \mathrm{mmol} / \mathrm{L}$ cetylpyridinium bromide (at the ratio 1:20, w/v) and stirred at $293 \mathrm{~K}$ for $24 \mathrm{~h}$. Then biosorbents were washed to $\mathrm{pH}=6$ with distilled water and dried at $323 \mathrm{~K}$ until the constant weight. After this modification by cetylpyridinium bromide the samples of biosorbents were designated: modified barley straw - BS-P, Jerusalem artichoke stalks JAS-P.

Methylene Blue (MB) and Acid Red (AR) were supplied by Ukraine company «Fine organic synthesis plant «Barva AG»»» and used without purification. The dye solutions were prepared by dissolving accurately weighted dyes in distilled water to the concentration of $1 \cdot 10^{-4} \mathrm{~mol} / \mathrm{L}$. Dyes characteristics are presented in Table 1.

Table 1. Dyes characteristics

\begin{tabular}{llcccc}
\hline Dye & Molecular structure & Formula & Molecular mass & Wavelength, nm & Size, nm $^{2}$ \\
\hline $\mathrm{MB}$ & & 319.5 & 670 & 0.99 \\
$\mathrm{AR}$ & & & & \\
$\mathrm{C}_{20} \mathrm{H}_{12} \mathrm{~N}_{2} \mathrm{~S}_{2} \mathrm{O}_{7} \mathrm{Na}_{2}$ & 502 & 490 & 1.26 \\
\hline
\end{tabular}

Adsorption of dyes was performed in static conditions. Biosorbents $(0.1 \mathrm{~g})$ in $10 \mathrm{~mL}$ of dye solution was shaking at $115 \mathrm{rpm}$ for $1 \mathrm{~h}$ (except specifically stated experiments). Dye concentration was determined spectrophotometrically after separation biosorbent.

The degree of dye adsorption removal was calculated by the formula

$\alpha=\frac{C_{0}-C}{C_{0}} \cdot 100$,

the adsorption of dyes was calculated by the formula

$$
A=\frac{C_{o}-C}{m} \cdot V \text {, }
$$

where $C_{o}$ - initial dye concentration; $C$ - dye concentration after adsorption; $m$ - mass of adsorbent; $V$ - volume of the dye solution.
The $\mathrm{pH}$ measurements of dye solutions were made using a pH-meter (model EV-74 with a glass electrode). Series of dye solutions were prepared by adjusting $\mathrm{pH}$ over a rang of $2-10$ using $1 \mathrm{M}$ hydrochloric acid or sodium hydroxide solution to investigate the effect of $\mathrm{pH}$ on dye adsorption.

Barley straw and Jerusalem artichoke stalks were studied by FTIR spectroscopy before and after the modification. FTIR spectra were recorded on Perkin-Elmer Spectrometer using KBr pellets.

\section{RESULTS AND DISCUSSION}

The effect of $\mathrm{pH}$ of the dye solution on the amount of adsorbed dye was studied by varying the initial $\mathrm{pH}$ under constant process parameters.

As elucidated in Figure $1 a$ for BS and JAS the removal percentages of cationic dye were minimum at the initial $\mathrm{pH}=2$. The main functional group is hydroxyl for these biosorbents. With the 
increase of $\mathrm{pH}$ value the concentration of $\mathrm{H}^{+}$ions (that compete with the dye cation for the adsorption sites) decreased, the percentages of cationic dye adsorbed on BS and JAS gradually increased when the initial $\mathrm{pH}$ was increased from $\mathrm{pH}=2$ to $\mathrm{pH}=10$. BS-C and JAS-C have carboxyl groups $-\mathrm{COOH}\left(\mathrm{pK}_{(-\mathrm{COOH})} \geq 5\right)$. When $\mathrm{pH}<5$, carboxyl group is turned into non-ionic form, cationic dye adsorption is decreased. When $\mathrm{pH}>5$, carboxyl group is turned into ionic form, cationic dye adsorption is increased.

For BS, BS-P, JAS and JAS-P the removal percentages of anionic dye were minimum at the initial $\mathrm{pH}>4$ (Fig. 1 b). It was believed that lower $\mathrm{pH}$ solution increases the positive charge on the adsorbent surface, which will attract the negatively charged functional groups located on the anionic dyes. When $\mathrm{pH}$ is increased, the amount of negatively charged sites on the adsorbent surface is also increased, thus the electrostatic interaction may be created between the adsorbent surface and dye anion.
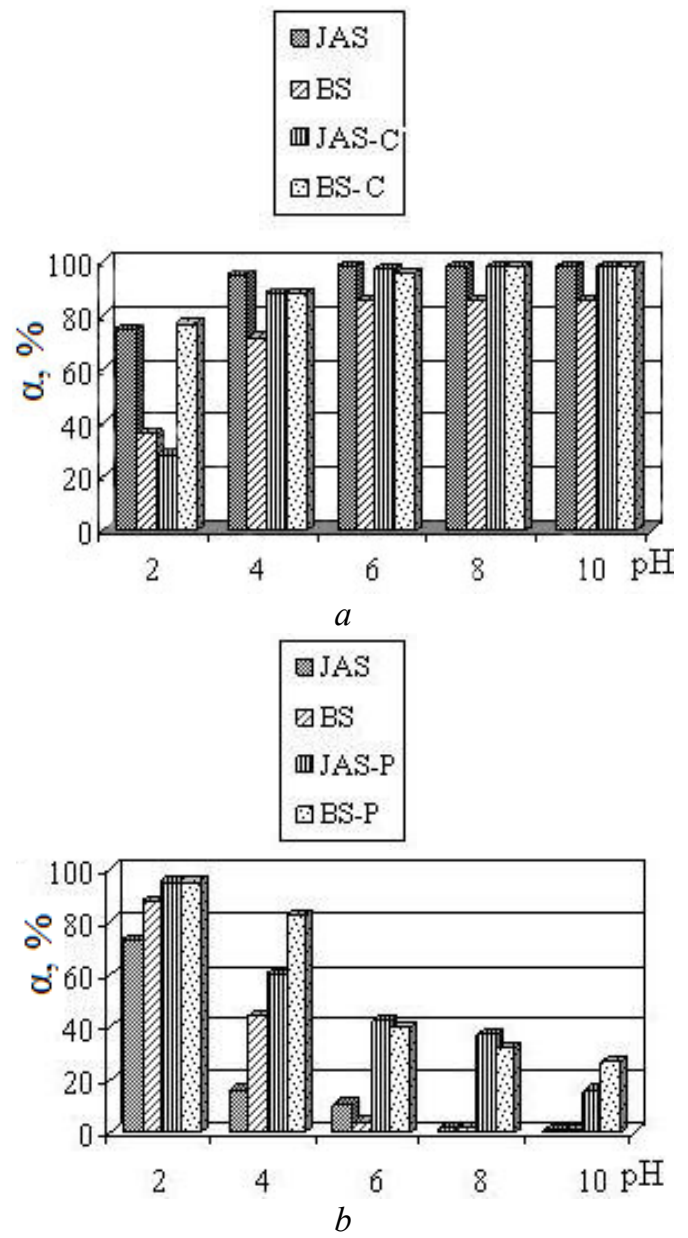

Fig. 1. Effect of $\mathrm{pH}$ on the $\mathrm{MB}(a)$ and $\mathrm{AR}(b)$ removal $(\alpha)$ onto biosorbents
The effect of the biosorbent dosage on the dye adsorption was investigated at different masses of biosorbents. The adsorption efficiency was increased slightly with the increasing of added absorbent amount. The optimum dosage of biosorbents for the removal of all investigated dyes is equal to $10 \mathrm{~g} / \mathrm{L}$ (Fig. 2). Further increasing of adsorbent dosage does not lead to increase of dyes removal percentage.

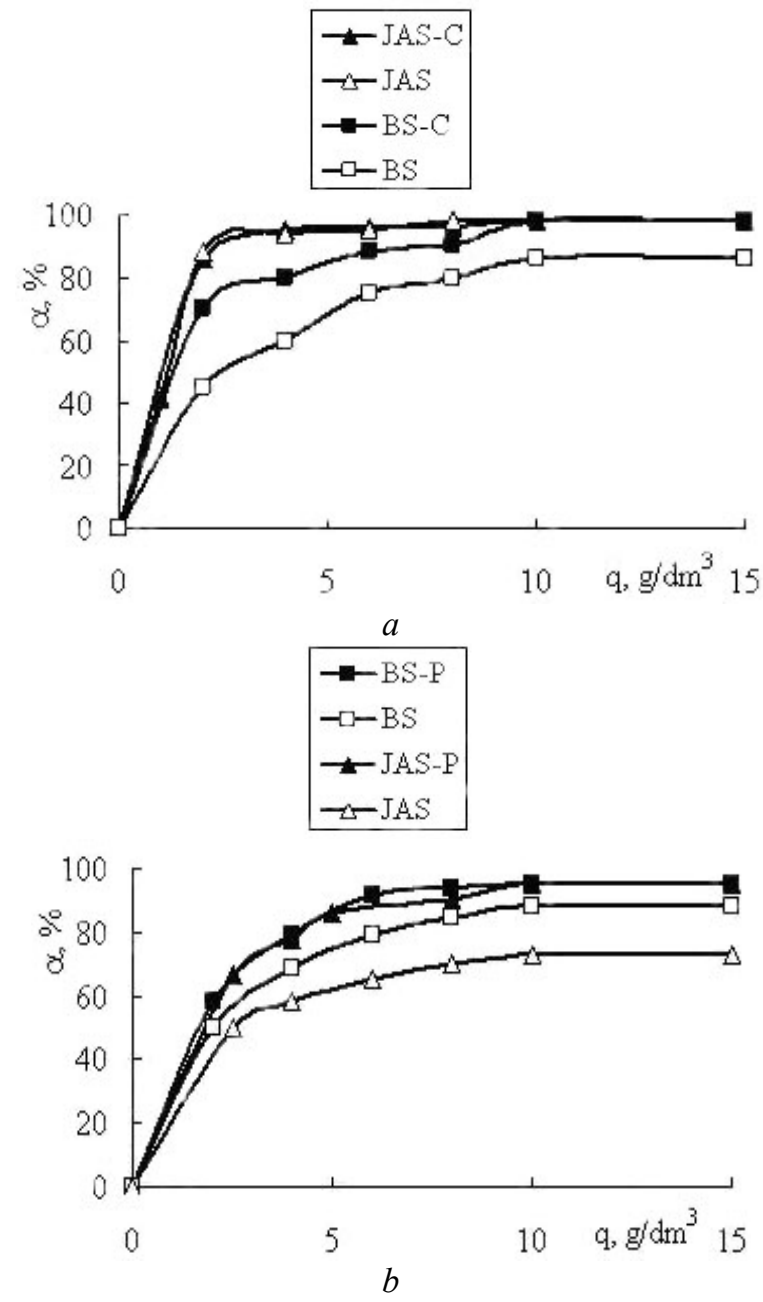

Fig. 2. Effect of biosorbent dosage (q) on the MB $(a)$ and AR $(b)$ removal $(\alpha)$ onto biosorbents

Adsorption kinetics is important in characterizing the efficiency of an adsorbent for use in the adsorption process. Determination of best-fit kinetic model is the most common way to predict the optimum adsorption kinetic expression. The experimental kinetic curves of dyes adsorption onto the studied biosorbents were analyzed with the pseudo-first and pseudosecond order kinetic equations. The linear form of pseudo-first order model equation and pseudo- 
second order model equation can be expressed, respectively, as

$$
\begin{aligned}
& \ln \left(A_{e}-A\right)=\ln A_{e}-k_{1} t, \\
& \frac{t}{A}=\frac{1}{k_{2} A_{e}^{2}}+\frac{1}{A_{e}} \cdot t,
\end{aligned}
$$

where $A_{e}$ and $A$ - amount of the dye adsorbed on the adsorbent at equilibrium and various time $t$, respectively; $k_{1}$ - adsorption rate constant of pseudo-first order model; $k_{2}$ - the adsorption rate constant of pseudo-second order model.

The kinetic curves of cationic and anionic dye adsorption on biosorbents are well described by a pseudo-second order kinetic equation (Tables 2,3). The values $A_{e, c a l}$ and values of correlation coefficients showed that the data conformed well to the pseudo-second order kinetic model.

Table 2. Pseudo- first order kinetic parameters for the removal of dyes onto biosorbents

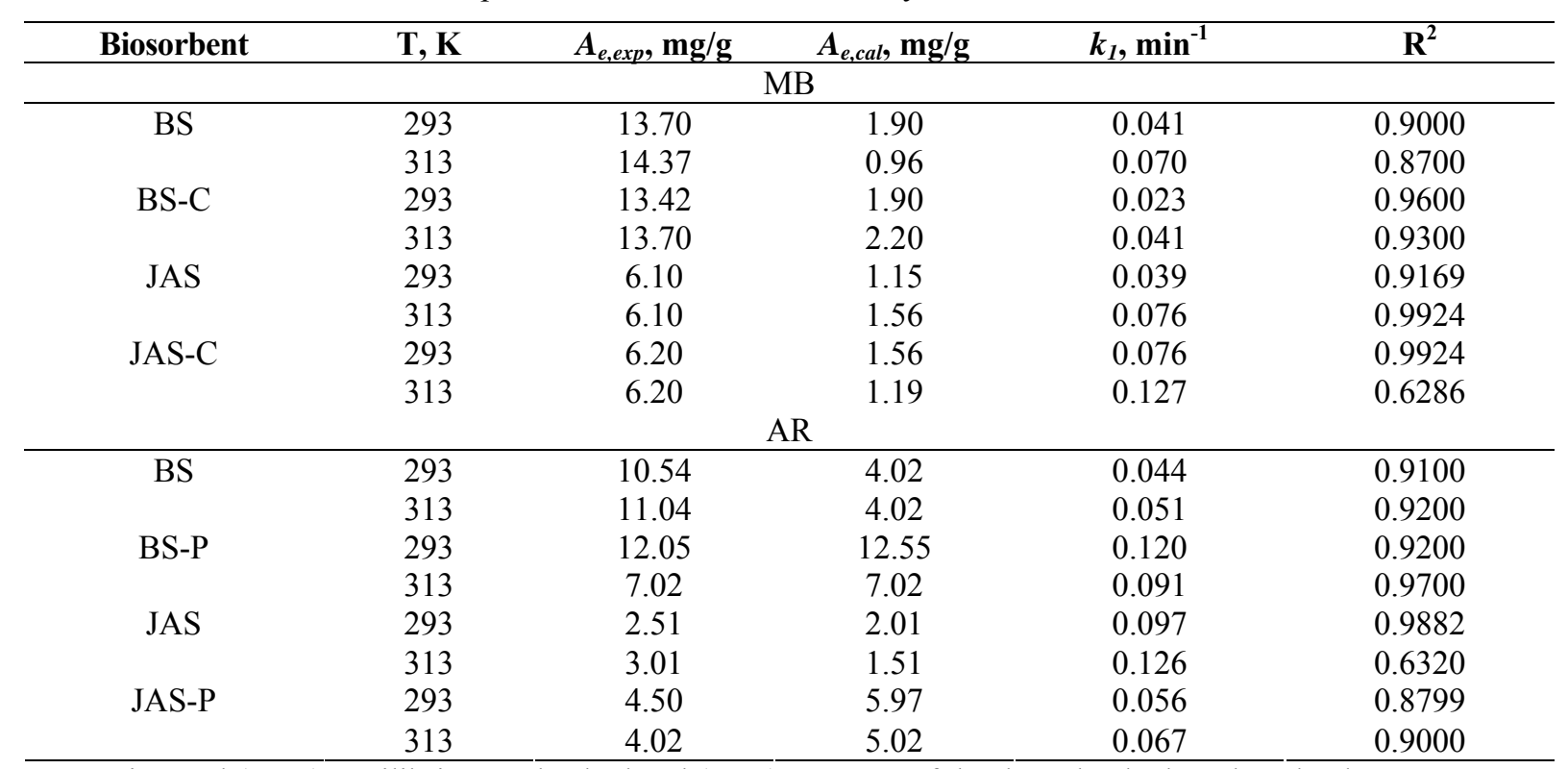

experimental $\left(A_{e, \text { exp }}\right)$ equilibrium and calculated $\left(A_{e, \text { cal }}\right)$ amounts of the dye adsorbed on the adsorbent

\begin{tabular}{|c|c|c|c|c|c|}
\hline Biosorbent & $\mathbf{T}, \mathbf{K}$ & $A_{e, e x p}, \mathrm{mg} / \mathrm{g}$ & $A_{e, \text { cal }}, \mathrm{mg} / \mathrm{g}$ & $k_{2},(\min \cdot g) / m g$ & $\mathbf{R}^{2}$ \\
\hline \multicolumn{6}{|c|}{ MB } \\
\hline \multirow[t]{2}{*}{ BS } & 293 & 13.70 & 14.06 & 0.034 & 0.9999 \\
\hline & 313 & 14.37 & 14.37 & 0.154 & 0.9999 \\
\hline \multirow[t]{2}{*}{ BS-C } & 293 & 13.42 & 13.42 & 0.040 & 0.9999 \\
\hline & 313 & 13.70 & 13.70 & 0.127 & 0.9999 \\
\hline \multirow[t]{2}{*}{ JAS } & 293 & 6.10 & 6.19 & 0.085 & 0.9999 \\
\hline & 313 & 6.10 & 6.16 & 0.150 & 1 \\
\hline \multirow[t]{3}{*}{ JAS-C } & 293 & 6.20 & 6.14 & 0.440 & 0.9986 \\
\hline & 313 & 6.20 & 6.21 & 0.457 & 1 \\
\hline & \multicolumn{5}{|c|}{ AR } \\
\hline \multirow[t]{2}{*}{$\overline{\mathrm{BS}}$} & 293 & 10.54 & 10.54 & 0.019 & 0.9999 \\
\hline & 313 & 11.04 & 12.05 & 0.023 & 0.9999 \\
\hline \multirow[t]{2}{*}{ BS-P } & 293 & 12.05 & 12.55 & 0.022 & 0.9999 \\
\hline & 313 & 7.02 & 11.04 & 0.029 & 0.9999 \\
\hline \multirow[t]{2}{*}{ JAS } & 293 & 3.01 & 3.01 & 0.093 & 0.9984 \\
\hline & 313 & 3.01 & 3.01 & 0.072 & 0.9997 \\
\hline \multirow[t]{2}{*}{ JAS-P } & 293 & 5.02 & 5.02 & 0.036 & 0.9978 \\
\hline & 313 & 4.52 & 4.52 & 0.023 & 0.9964 \\
\hline
\end{tabular}

Table 3. Pseudo-second order kinetic parameters for the removal of dyes onto biosorbents 
Adsorption of anionic dye onto BS-P and JAS-P decreased with increasing temperature indicating exothermic nature of adsorption. Adsorption of anionic dye onto BS or JAS and that of cationic dye onto BS or BS-C increased with increasing temperature so indicating endothermic nature of adsorption.
The unmodified and modified BS, unmodified and modified JAS have typical lignocelluloses composition (Table 4). The IR spectra of unmodified and modified samples slightly differ. This indicates that the process of agricultural waste modification is soft. There is no significant destruction of intermolecular bonds between lignin and cellulose.

Table 4. FTIR spectra of biosorbents

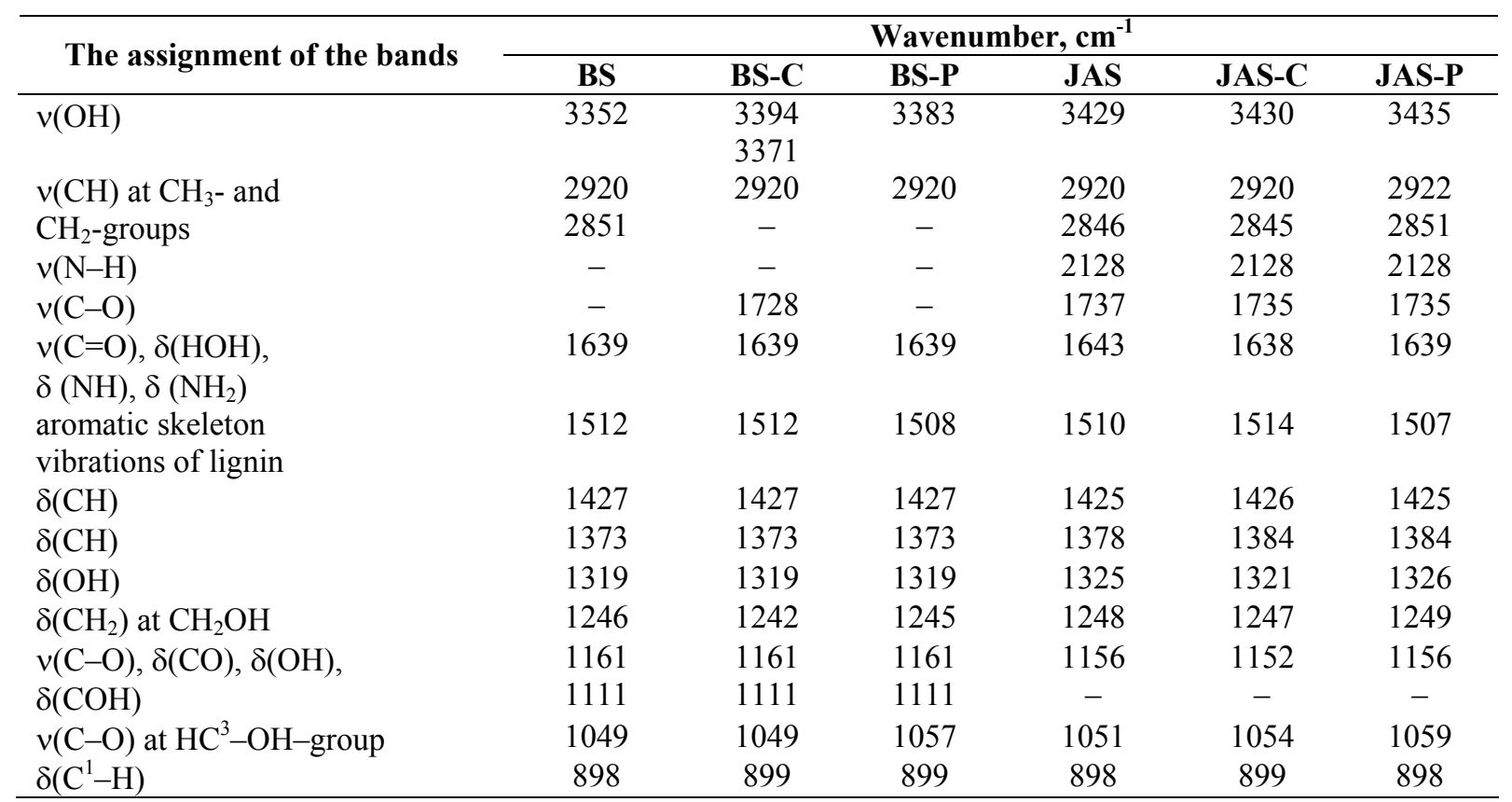

The band $v(\mathrm{OH})$ shifts to higher frequencies for modified adsorbents in comparison with that unmodified ones due to the weakening of the hydrogen bonds between the cellulose and lignin in the agricultural waste after its modification [7].

Comparing IR-spectrum of BS with that of BS-C shows that there is a strong characteristic stretching vibration adsorption band of carboxyl group at $1728 \mathrm{~cm}^{-1}$ in the IR spectrum of BS-C. It reflects the result of biosorbent modification by citric acid. Comparing IR-spectra of JAS and JAS-C shows that the unmodified adsorbent JAS has carboxyl groups and its modification by citric acid is inappropriate.

Table 4 shows that the modification of the BS and JAS by cetylpyridinium bromide leads to disappearance of the band $2851 \mathrm{~cm}^{-1}$ in BS-P and to its appearance in JAS-P.

\section{CONCLUTIONS}

Studied biosorbents are natural, eco-friendly and low-cost adsorbents with relatively large adsorption capacity and they can be an alternative to expensive activated carbons.

The adsorption of dye onto unmodified and modified barley straw and Jerusalem artichoke stalks is strongly affected by the $\mathrm{pH}$ value. The optimum $\mathrm{pH}$ is in the range of 6-10 for cationic dye and 2-3 for anionic dye. The variation in the extent of dye removal with $\mathrm{pH}$ has been explained on the basis of surface ionization and nature of dyes.

The kinetic curves of cationic and anionic dyes adsorption on barley straw and Jerusalem artichoke stalks are well described with the help of pseudo-second order kinetic equation.

\section{REFERENCES}

1. Gupta V.K., Suhas. Application of low-cost adsorbents for dye removal (review) // J. Environ. Manag. - 2009. - V.90. P. 2313-2342.

2. Zapolsky A.K., Mishkova-Klimenko N.A., Astrelin I.M. et al. Physico-chemical Basis of 
Technology of Sewage Treatment. - Kyiv: Libra, 2000. - 552 p. (in Ukrainian).

3. Klyus S.V., Zabarny G.N. Assessment and forecast capacity of solid biofuels in Ukraine // Compres. Power Engi. - 2011. - N 2. - P. 8 13 (in Ukrainian).

4. Anikienko T.I. Scientific and practical rationale of the use of high-energy feed from Jerusalem artichoke in diets of cows in southern East Siberia: Thesis for the academic degree Doctor of Agriculture Sciences, Krasnoyarsk - 2009. (in Russian).
5. Mussatto S.I., Teixeira J.A. Lignocellulose as raw material in fermentation processes // Current Research, Technology and Education Topics in Applied Microbial Biotechnology (A.Mendez-Vilas (ed.)). - Badajoz, 2010. P. 897-907.

6. Nikiforova T.E., Kozlov V.A., Bagrovskaya N.A., Rodionova M.V. Sorption cleaning of wines // Chemistry of plant raw materials. 2007. - N 1. - P. 69 - 73 (in Russian).

7. Petropavlovsky A.G. Microcrystalline cellulose (review) // Wood Chemistry. - 1979. - N 6. P. 3-21 (in Russian).

Received 30.10.2012, accepted 18.01.2013

\title{
Застосування агропромислових відходів як біосорбентів для вилучення барвників із водних розчинів
}

\author{
Л.М. Солдаткіна, М.А. Заврічко \\ Одеський національний університет імені I.I. Мечникова \\ вул. Дворянська, 2, Одеса, 65082, Україна, soldatkina@опи.еdu.иа
}

Вивчена ефективність немодифікованих та модифікованих біосорбентів (солома ячменю і стебла топінамбура) при вилученні аніонного (кислотний червоний) та катіонного (метиленовий блакитний) барвників з їх водних розчинів. Встановлено, що адсорбиія барвників на немодифікованих та модифікованих біосорбентах істотно залежить від значення $p H$. Оптимальні значення $p H$ спостерігаються в діапазоні 6-10 для катіонного і 2-3 для аніонного барвника. Кінетичні криві адсорбиї барвників на соломі ячменю і стеблах топінамбура добре описуються кінетичним рівнянням псевдодругого порядку. Досліджені біосорбенти - екологічно чисті та дешеві природні матеріали, вони можуть бути альтернативою активованому вугіллю.

\section{Применение агропромышленных отходов как биосорбентов для выделения красителей из водных растворов}

\section{Л.М. Солдаткина, М.А. Завричко}

Одесский национальный университет имени И.И. Мечникова ул. Дворянская, 2, Одесса, 65082, Украина, soldatkina@опи.edu.иа

Изучена эффективность немодифищированных и модифищированных биосорбентов (солома ячменя и стебли топинамбура) при выделении анионного (кислотный красный) и катионного (метиленовый голубой) красителей из водных растворов. Установлено, что адсорбиия красителей на немодифицированных и модифицированных биосорбентах существенно зависит от значения $р H$. Оптимальные значения рН наблюдаются в диапазоне 6-10 для катионного красителя и 2-3 для анионного. Кинетические кривые адсорбции красителей на соломе ячменя и стеблях топинамбура хорошо описываются кинетическим уравнением псевдовторого порядка. Исследованные биосорбенты являются экологически чистыми и дешевыми природными материалами, они могут быть альтернативой активным углям. 